\title{
Geophysical Investigation for Engineering Site Development around Galadimawa-Aleita Area, Abuja, North Central Nigeria
}

\author{
Longpia, C.B ${ }^{1}$, Ashano E.C ${ }^{2}$, Pam B.G. ${ }^{3}$ \\ Department of Mineral Resources Engineering, Plateau State Polytechnic, Barkin Ladi \\ Department of Geology and Mining, University of Jos, Jos \\ Department of Civil Engineering, Plateau State Polytechnic, Barkin Ladi
}

\begin{abstract}
Fifty five (55) geo-electric resistivity soundings (VES) were carried out in profiles at interval of $250 \mathrm{~m}$ and station interval of $200 \mathrm{~m}$ around Galadimawa-Aleita area, Abuja in an attempt to have some detailed geotechnical information for planning purposes as regards infrastructural development which include buildings, roads, bridges and water supply through groundwater resources. The computer aided VES data interpretation enabled the determination and delineation of geo-electric layers and structures that have significance in infrastructural development and water supply. Geo-electric sections revealed 3-4 geo-electric layers/lithologic units of topsoil, laterite, weathered basement and resistive bedrock and are characterised by resistivity values of 122 to $600 \mathrm{ohm}-\mathrm{m}, 800$ to $3385 \mathrm{ohm}-\mathrm{m},<100$ to $5000 \mathrm{ohm}-\mathrm{m}$ and $120 \mathrm{ohm}-\mathrm{m}$ to infinity respectively. Variable thicknesses of 0.8 to $8 \mathrm{~m}, 0.1-1 \mathrm{~m}$, and 4-8m were recognized for topsoil, laterite and weathered basement respectively. Depth to bedrock is variable from 0.8-24m across the area.Fractures were identified across the area with complex and major deformation around the central area, near the two abandoned quarries. These quarries were submerged by water issuing out of the sub-surface fault system which led to their abandonment by the quarry operators. The study revealed that overburden materials overlying bedrock are thin and characterized by minor and major fracturation which are significant in infrastructural development planning.
\end{abstract}

Keywords: Geophysical investigation, geotechnical planning, infrastructural development, Galadimawa-Aleita area, Abuja.

\section{Introduction}

The use or application of geo-electric resistivity method for engineering site investigation and groundwater search in the last few decades has been on the increase due to its level of success, relatively cheap cost, appreciable accuracy and speed. Its application is mainly in the determination of depth to bedrock, nature of superficial deposit and structural mapping (Olorunfemi and Mesida 1987, Olorunfemi and Okhue 1992, Omosuyi et.al, 2003, Idornigie and Lawal (2006); Akintorinwa and Adeusi, 2009). The success of the method depends mainly on its significant and detectable contrast in the earth materials.

Galadimawa-Aleita old settlements in Lugbe District, Abuja along the Abuja Airport Express Way are potential areas for modern physical infrastructural development such as buildings, roads and bridges and possibly water supply. Therefore, the need to have detailed geotechnical information about the area has become necessary for planning purposes. It is in view of this fact that geophysical investigation employing vertical electrical soundings (VES) were carried out to determine the depth to bedrock, nature of superficial deposits, subsurface geological structures and groundwater potentials to provide a data base that will assist in any infrastructural development planning. 

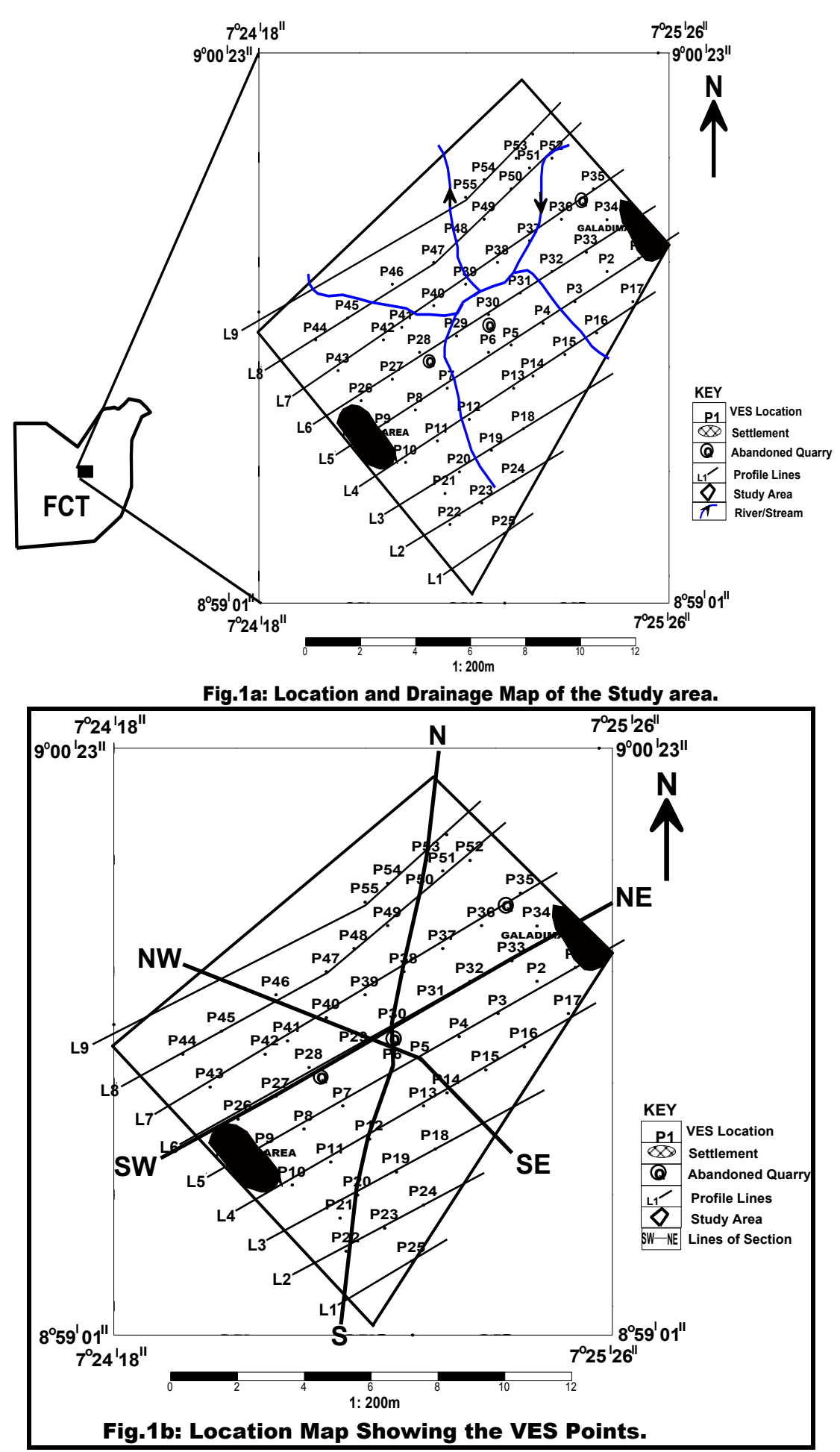

\section{Physiography}

Galadimawa-Aleita area lies between longitude $7^{\circ} 24^{\mathrm{I}} 18^{\mathrm{II}}$ and $7^{\circ} 25^{\mathrm{I}} 26^{\mathrm{II}}$ and latitude $8^{\circ} 59^{\mathrm{I}} 01^{\mathrm{II}}$ and $9^{\circ} 00^{\mathrm{I}} 23^{\mathrm{II}}$ (Fig.1). The area is relatively undulating and generally slopes from the west and east towards the main drainage line and elevation varies between $410-453 \mathrm{~m}$ above mean sea level.

The area is dissected by perennial streams to the east, south east, northwest and southwest. The predominant vegetation cover is typically of the Guinea Savannah and is characterized by the presence of palm trees, Parki spp, Anona Senegalensis, Daniella Oliveri, Pilios Tigma spp and Prosopis spp (ABU Consult, 1999).

The area is characterized by relics of rock quarries in the northeastern and central part. The central quarries have been flooded with water. 


\section{Geology}

Offodile (2003) have described in some details the geology of the Federal Capital Territory(FCT), Abuja. It is underlain by two major rock formations - the Basement Complex and sedimentary rock formations (Fig 2). The stratigraphic succession is as follows:

\begin{tabular}{|l|l|l|}
\hline S/No & Formation & Age \\
\hline 1. & Alluvium & Quaternary-Recent \\
\hline 2. & Nupe sandstone & Tertiary \\
\hline 3. & Basement complex & Pre-Cambrian \\
\hline
\end{tabular}

\section{Basement Complex}

The Basement Complex consists essentially of undifferentiated Precambrian rocks. This rock type underlies about $90 \%$ of the FCT and the rocks are distinguished in broad terms into migmatites, Older Granites and metasediments. The meta-sediments are generally restricted to the southeastern part of the Territory and occur as isolated strips and patches within the granite massifs.

\section{The Nupe Sandstone}

The Nupe Sandstone consists of argillaceous beds overlying sandy and gritty clays, clay stone and some conglomerates.

\section{Alluvium}

The Alluvium comprises of medium to coarse-grained river sands, silts and clays. It is generally confined to the riverbeds of the major drainage network of Gurara, Usuma and Robo.

Within the study area, the main lithologic units are migmatites, and migmatitic-gneiss which outcrops in the form of isolated hills in the north, northwest and southwestern segment of the area. The low lying areas are covered by soils derived mainly from the weathering of the basement rocks and occupies $>95 \%$ of the area.

The underlying rocks are only exposed at the quarries and within the stream channels. The general structural fabric strike $330 \mathrm{NW}$.

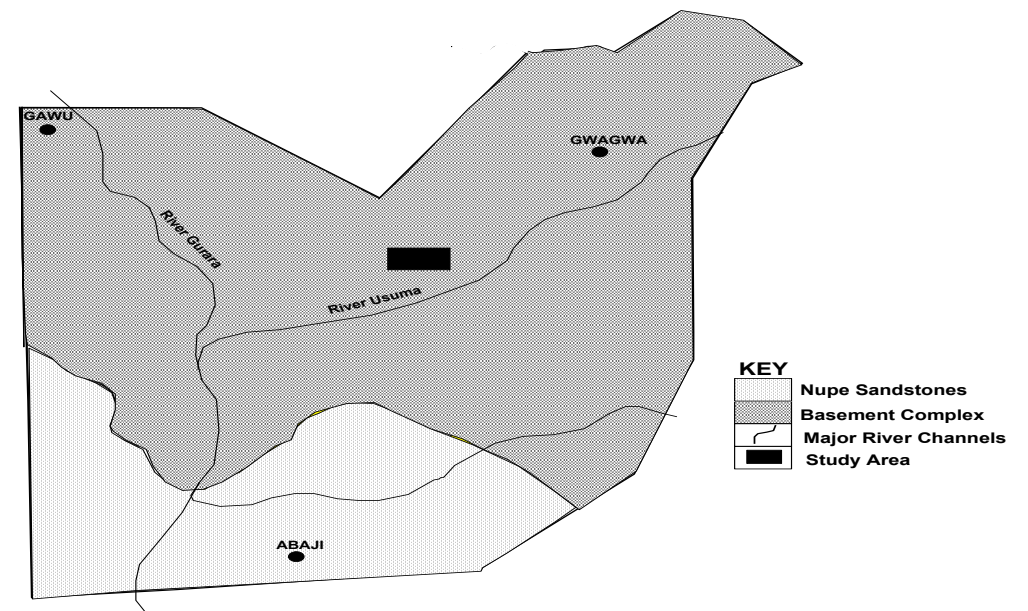

Fig 2: Geological Map of Federal Capital Territory, Abuja (Modified after NGSA (1984-1985)

\section{Geophysical Investigation}

The geophysical method used for the investigation programme was the geo-electrical resistivity sounding method employing the vertical electrical sounding technique (Schlumberger array) with current electrode or half electrode spacing $\mathrm{AB} / 2$ spreading from 1.5 to $125 \mathrm{~m}$. Measurements were made with increasing separation between current electrodes. The data for each spacing were recorded as apparent resistivity, which was multiplied by a geometric factor $(\mathrm{K})$ to give apparent resistivity. A total of 55 VES numbered P1-P 55 were carried out at grid points established at intervals of $200 \mathrm{~m}$ in profiles numbered L1 to L9 (Fig. 1a). The earth resistivity measurement was carried out using ABEM Terrameter SAS 1000 model.

The VES were interpreted using VES interpretation software - Win Resist Version 1.0 (Vander Velpen, 1988, 2004) which is based on smoothness constrained optimization technique. The co-ordinates and elevation of the VES locations were obtained by the Garmin etrex 12 channel Global Positioning system. 


\section{Results And Discussion}

The VES curve types identified in the area include: - A, AK, H, HK, QH, HKA, HA with $\mathrm{H}$ as the predominant curve type. The typical curve types are as shown in Fig 3(a-c). Table 1 gives the summary of the VES interpretation.

Table 1: Summary of VES Interpretation Result

\begin{tabular}{|c|c|c|c|c|c|c|c|c|c|}
\hline \multirow[t]{2}{*}{ VES } & \multirow[t]{2}{*}{ Curve Type } & \multicolumn{4}{|c|}{ Layer Resistivity (Ohm-m) } & \multicolumn{4}{|c|}{ Layer Thickness (m) } \\
\hline & & $\ell 1$ & $\ell 2$ & 13 & $\ell 4$ & h1 & h2 & h3 & h4 \\
\hline P1 & QH & 513 & 1285 & 120 & $\geq 136$ & 1.2 & 3.7 & 11.8 & \\
\hline $\mathbf{P 2}$ & $\mathbf{H}$ & 2488 & 173 & 383 & & 4.4 & 4 & & \\
\hline P3 & $\mathbf{H}$ & 219 & 98 & 397 & & 1.2 & 4.27 & & \\
\hline P4 & $\mathbf{H}$ & 287 & 172 & 323 & & 1.7 & 3.74 & & \\
\hline P5 & $\mathbf{H}$ & 794 & 188 & 351 & & 1.2 & 3.72 & & \\
\hline P6 & AKA & 175 & 389 & 305.5 & 382 & 1.1 & 3.82 & 5.68 & \\
\hline P7 & $\mathbf{H}$ & 347 & 159 & 402 & & 1.2 & 4.27 & & \\
\hline P8 & $\mathbf{H}$ & 525 & 188 & 931 & & 1.3 & 11.8 & & \\
\hline P9 & $\mathbf{A}$ & 196 & 394 & - & & 3.35 & & & \\
\hline P10 & AK & 487 & 2027 & 1914 & & 2.3 & 8.32 & 12.4 & \\
\hline P11 & $\mathbf{H}$ & 390 & 163 & 445 & & 1.1 & 2.25 & & \\
\hline P12 & H & 1162 & 90.7 & 392 & & 0.7 & 2.65 & & \\
\hline P13 & $\mathbf{H}$ & 365 & 130 & 383 & & 2.5 & 5.5 & & \\
\hline P14 & AK & 644 & 3478 & 2205 & & 3.4 & 19.45 & & \\
\hline P15 & $\mathbf{H}$ & 474 & 158.3 & 539 & & 2.8 & 10.3 & & \\
\hline P16 & $\mathbf{H}$ & 433 & 87 & 456 & & 0.8 & 10.9 & & \\
\hline P17 & $\mathbf{Q H}$ & 1303 & 310 & 626 & & 6.1 & 13.1 & & \\
\hline P18 & $\mathbf{A}$ & 806 & - & - & & 1.1 & - & & \\
\hline P19 & HK & 1443 & 413 & 1914 & 1207 & 1.3 & 4.8 & 22 & \\
\hline P20 & HK & 255 & 137 & 448 & & 0.7 & 2.36 & 10.6 & \\
\hline P21 & $\mathbf{H}$ & 694 & 165 & 501 & & 0.8 & 7.2 & & \\
\hline P22 & HKA & 1121 & 500 & 790 & 1000 & 0.9 & 3.5 & 6 & 7 \\
\hline P23 & $\mathbf{H}$ & 354 & 71 & 266 & & 2.8 & 9 & & \\
\hline P24 & $\mathbf{A}$ & 429 & 1047 & & & 4.9 & $\infty$ & & \\
\hline P25 & $\mathbf{H}$ & 1284 & 375 & 904 & & 1.4 & 15.5 & 904 & \\
\hline P26 & $\mathbf{H}$ & 248 & 171 & 434 & & 1.3 & 12.1 & 434 & \\
\hline P27 & H & 566 & 82 & 329 & & 0.8 & 4.7 & 329 & \\
\hline P28 & AK & 478 & 2105 & 454 & 1677 & 4.8 & 9 & 28 & \\
\hline P29 & HK & 1504 & 659 & 755 & 2440 & 1.7 & 1.9 & 5 & 9 \\
\hline P30 & AK & 7624 & 18508 & 3609 & 8505 & 1.2 & 4.3 & 19.5 & \\
\hline P31 & $\mathbf{H}$ & 919 & 138 & 699 & & 0.8 & 1.74 & & \\
\hline P32 & $\mathbf{H}$ & 693 & 143 & 391 & & 1.73 & 3.77 & & \\
\hline P33 & $\mathbf{H}$ & 366 & 110 & 363 & & 1.1 & 2.62 & & \\
\hline P34 & HA & 897 & 265 & 707 & 1538 & 0.8 & 2.92 & & \\
\hline P35 & HKA & 429 & 1994.5 & 3638 & 2143 & 0.9 & 9.2 & 12.9 & \\
\hline P36 & HA & 137 & 88 & 399 & 1155 & 0.7 & 4.13 & 9.1 & \\
\hline P37 & $\mathbf{H}$ & 3043 & 826 & 1188 & & 1.92 & 2.22 & & \\
\hline P38 & HA & 525 & 161 & 368 & 1356 & 1.2 & 4.3 & 6.2 & \\
\hline P39 & HKA & 675 & 368 & 4699 & & 0.9 & 3.2 & 8.96 & 12.2 \\
\hline P40 & HA & 482 & 126 & 524 & & 1.2 & 4.3 & 9.3 & \\
\hline P41 & $\mathbf{H}$ & 978 & 168 & 442 & & 1.3 & 11.8 & & \\
\hline P42 & HA & 258 & 164 & 616 & 2781 & 1.2 & 2.5 & 9.3 & \\
\hline P43 & HKH & 1177 & 359 & 779 & 281 & 0.9 & 1.92 & 3.3 & 13.11 \\
\hline P44 & QH & 524 & 712 & 288 & 535 & 6.1 & 13.1 & & \\
\hline P45 & $\mathbf{H}$ & 153 & 62 & 451 & - & 1.7 & 6.3 & - & \\
\hline P46 & $\mathbf{H}$ & 651 & 51 & - & - & 1.2 & 5.8 & & \\
\hline P47 & $\mathbf{H}$ & 723 & 60 & 270 & & 1.2 & 6.8 & & \\
\hline P48 & $\mathbf{H}$ & 1007 & 183 & 679 & & 0.8 & 7.2 & & \\
\hline P49 & A & 155 & 478 & - & & 8 & & & \\
\hline P50 & AK & 569 & 3761 & 2678 & 2549 & 1.2 & 4.3 & 29 & \\
\hline P51 & $\mathbf{H}$ & 712 & 126 & 501 & & 0.9 & 8.1 & & \\
\hline P52 & $\mathbf{H}$ & 389 & 223 & 481 & & 0.8 & 7.2 & & \\
\hline P53 & HK & 326 & 180 & 675 & 523 & 0.8 & 4.7 & 2.5 & 17 \\
\hline P54 & $\mathbf{H}$ & 523 & 248 & 1231 & - & 1.7 & 5.3 & - & \\
\hline P55 & $\mathbf{H}$ & 579 & 118 & 498 & & 0.8 & 4.3 & & \\
\hline
\end{tabular}

The results and the interpretation of the various VES curves are presented accordingly as geo-electric sections, histograms and maps which are discussed below: - 


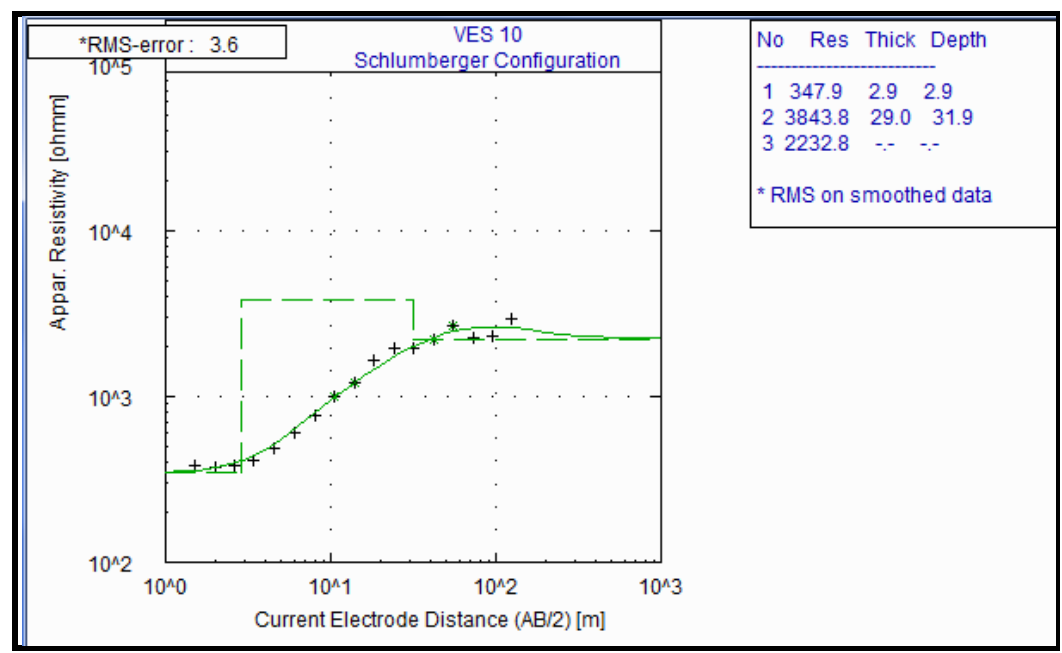

Fig.3a: A Type Curve

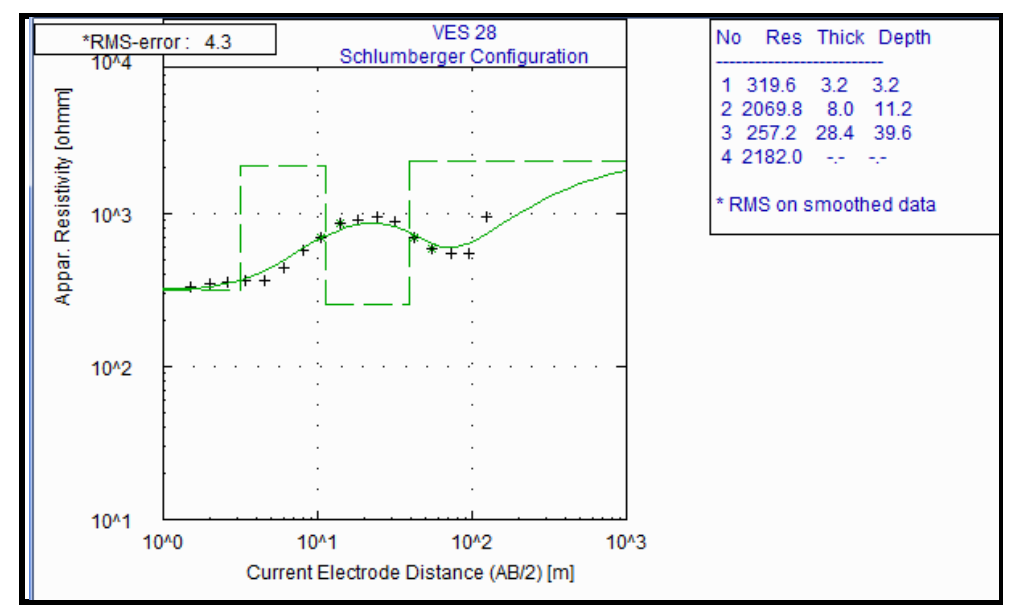

Fig.3b: AK Type Curve

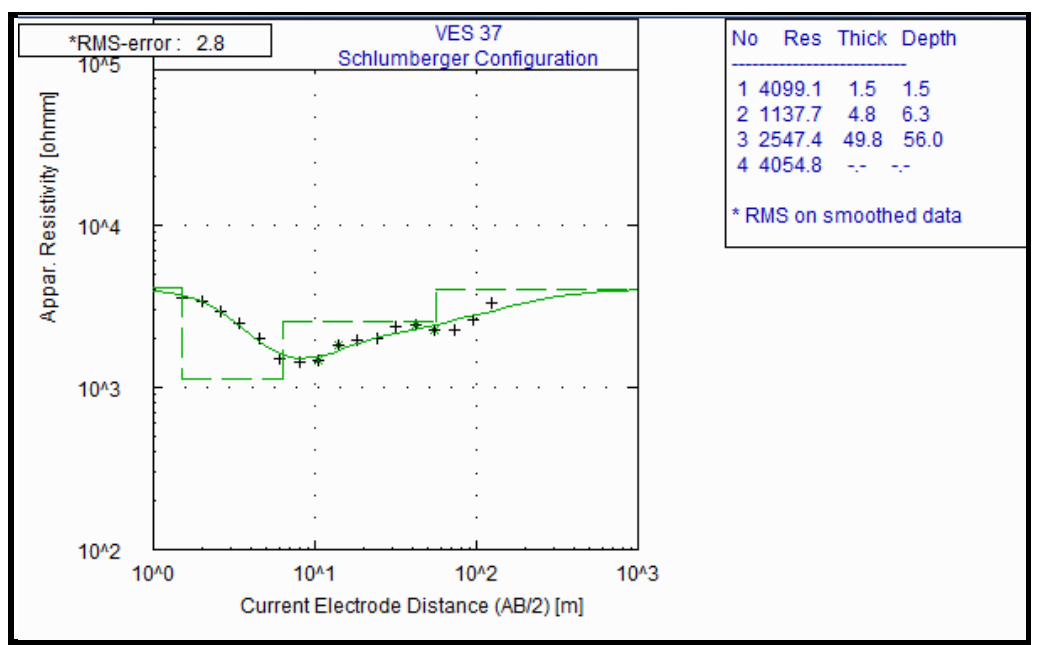

Fig 3c: H Type Curve

\section{Geo-electric Sections}

Four geo-electric sections are drawn in three directions N-S, NE-SW and NW-SE (Fig.1b) for correlation of the geo-electric sequence across the study area (Fig 4-6). A maximum of four geo-electric or subsurface layers are identified beneath these sections. Typical VES curves in the study area as shown in Fig.3. The layers identified include the topsoil, lateritic layer, weathered layer (comprising clay, sandy clay and sand) and resistive basement/bedrock. 
Histograms of the delineated geo-electric layer resistivity are as shown in Fig.7. The topsoil resistivity is characterized by resistivity values ranging from 122 to $513 \mathrm{ohm}-\mathrm{m}$. The low resistivity values of $<200 \mathrm{ohm}-\mathrm{m}$ is characteristic of clayey sand/sandy clay, while moderate resistivity of $>200$ to $600 \mathrm{ohm}-\mathrm{m}$ are characteristic of compact sand, lateritic sand and sands. The layer thicknesses range from $0.8-8 \mathrm{~m}$ with the most frequent value range occurring in the 1-2 $\mathrm{m}$ thick range.

The second layer (lateritic layer) as shown in Fig. 7b shows resistivity values varying from 800-3385 ohm-m. Resistivity value of $800-1400 \mathrm{ohm}-\mathrm{m}$ is more or less lateritic sand, compact lateritic sand or laterite. High resistivity values of 2400-3200 are characteristic of lateritic iron stone (hardpan). The most frequent layer resistivity occurs in the $800-1200 \mathrm{ohm}-\mathrm{m}$ range with layer thicknesses varying between 0.1 and $1.0 \mathrm{~m}$ (Fig $8 \mathrm{~b}$ ). The lateritic layer is generally absent in most of the VES stations except in the northeastern part around VES 1, 2 and 3.

The third layer (weathered basement) which consists of sand or sandy clay has an average resistivity range of $<100$ to $500 \mathrm{ohm}-\mathrm{m}$ (Fig 7c), with the most frequently occurring resistivity in the 100-200 ohm-m range. The most frequently occurring thickness range of this layer occurs in the 4-8m (Fig.8c).

This layer resistivity value is characteristically lower than other layers and this could be adduced to as a result of water saturation (Omosuyi et'al, 2003) of the weathered overburden overlying the fresh basement.

The bedrock layer has a resistivity value variable from 120 to $4800 \mathrm{ohm}-\mathrm{m}$. The fresh bedrock resistivity is generally $>1000 \mathrm{ohm}-\mathrm{m}$. Some VES locations revealed fractures (Fig 4-6) with significant drop in the resistivity values, which drop could be as a result of water saturation in the fractured basement. Fractures in the crystalline rocks acts as conduit for flow and groundwater storage.
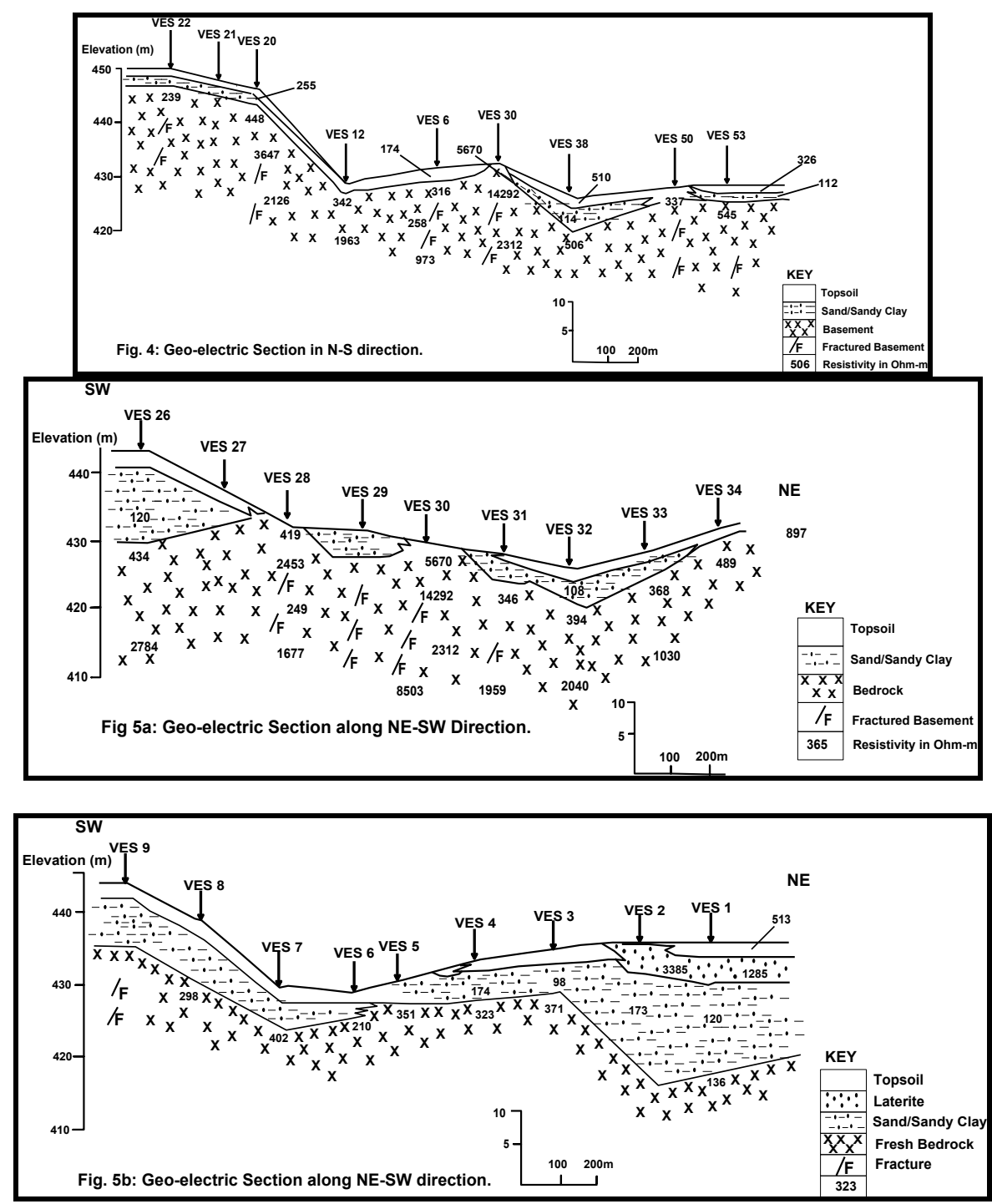

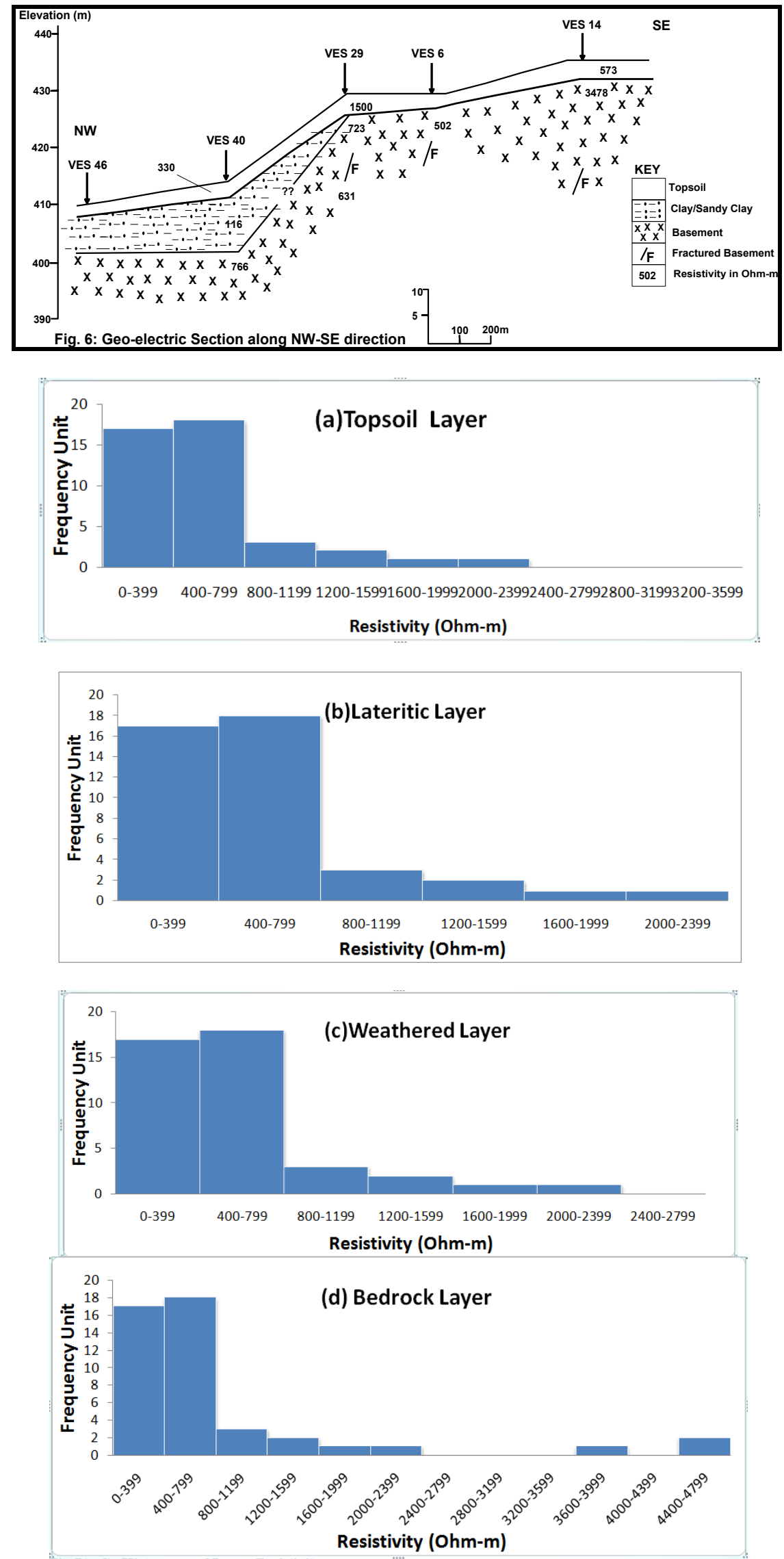

Fig 7(a-d): Histogram of Layer Resistivity 

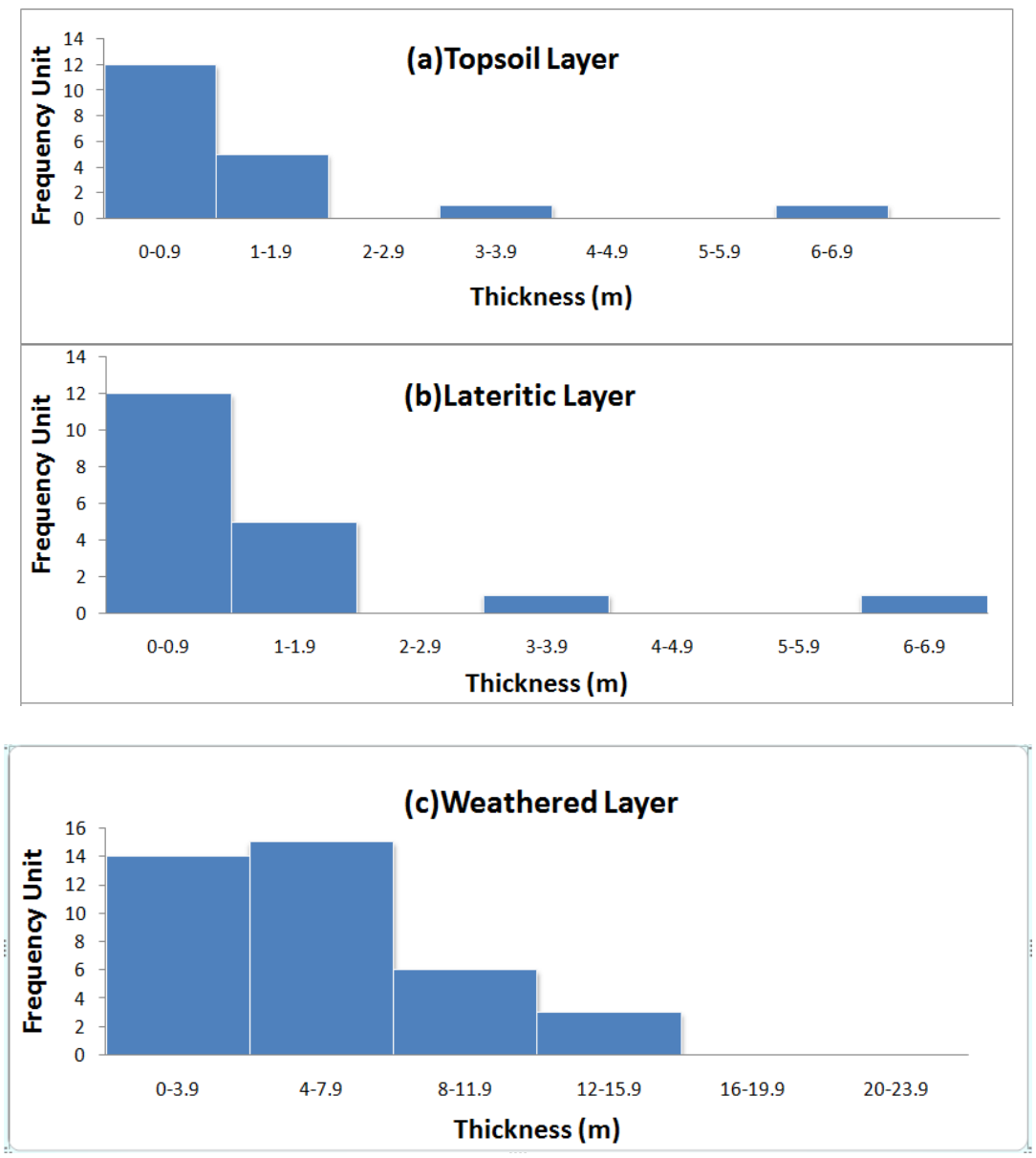

Fig 8(a-c): Histogram of Layered thickness

\section{Geo-electric Structure}

Although all the geo-electric sections (Fig.4-6) revealed some level of subsurface fractures, the VES 27-28-29-30 axis (Fig 5a) is characterized by complex fracturation and structural deformation at about $8 \mathrm{~m}$ dept. The two large quarries sited west of VES 28 and 29 have been abandoned by the former operator as a result of subsurface fault systems of the area. The quarrying activities may have intercepted the major fault mapped by VES stations 27, 28, 29 and 30 which started at about $8 \mathrm{~m}$ depth and continued past $40 \mathrm{~m}$. The quarries located to the south of the area also intercepted the fault and its extension.

\section{Isopach Map of the Overburden}

Fig.9 shows the contour map of the overburden thickness established over the VES stations in the surveyed area. The map shows a variable overburden thickness from $<2-24 \mathrm{~m}$.

The northeastern extreme of the area together with some isolated areas in the south west has relatively thick overburden cover of between $10-24 \mathrm{~m}$. The other areas have relatively thin overburden ranging between $<$ 2 and $5 \mathrm{~m}$. Where the basement outcrops, the overburden thickness is virtually zero. The rock outcrops are in the form of isolated hills. For engineering purposes, the shallow depth to basement is an indication of shallow depth to firm foundation bed across the study area.

\section{Bedrock Relief}

The bedrock relief map (Fig.10) is a contoured map of the bedrock elevations established beneath the VES stations. According to Olorunfemi and Okhue (1992), the significance of the bedrock relief map is to show the reflection of the bedrock topography and its structural disposition.

From Fig. 10 a series of ridges and depression which are marked $\mathrm{R}$ and $\mathrm{D}$ respectively can be recognized. The main depressions are found in the SSW and SSE zones of the study area and in some isolated areas (Fig $4,5 \& 6$ ). The width of the depressions varies between $20-400 \mathrm{~m}$. The depressions are covered with variable thickness of overburden between $<2-21 \mathrm{~m}$ (see Fig 9).

The depressions serve as collecting troughs for surface and groundwater. Where thick overburden overlies depressions, they are potential zone for groundwater development. It appears that the thick overburden 
overlying the depressions must have been washed away as a result of the streams that flow within the depressed areas and exposing the bedrock in some places.

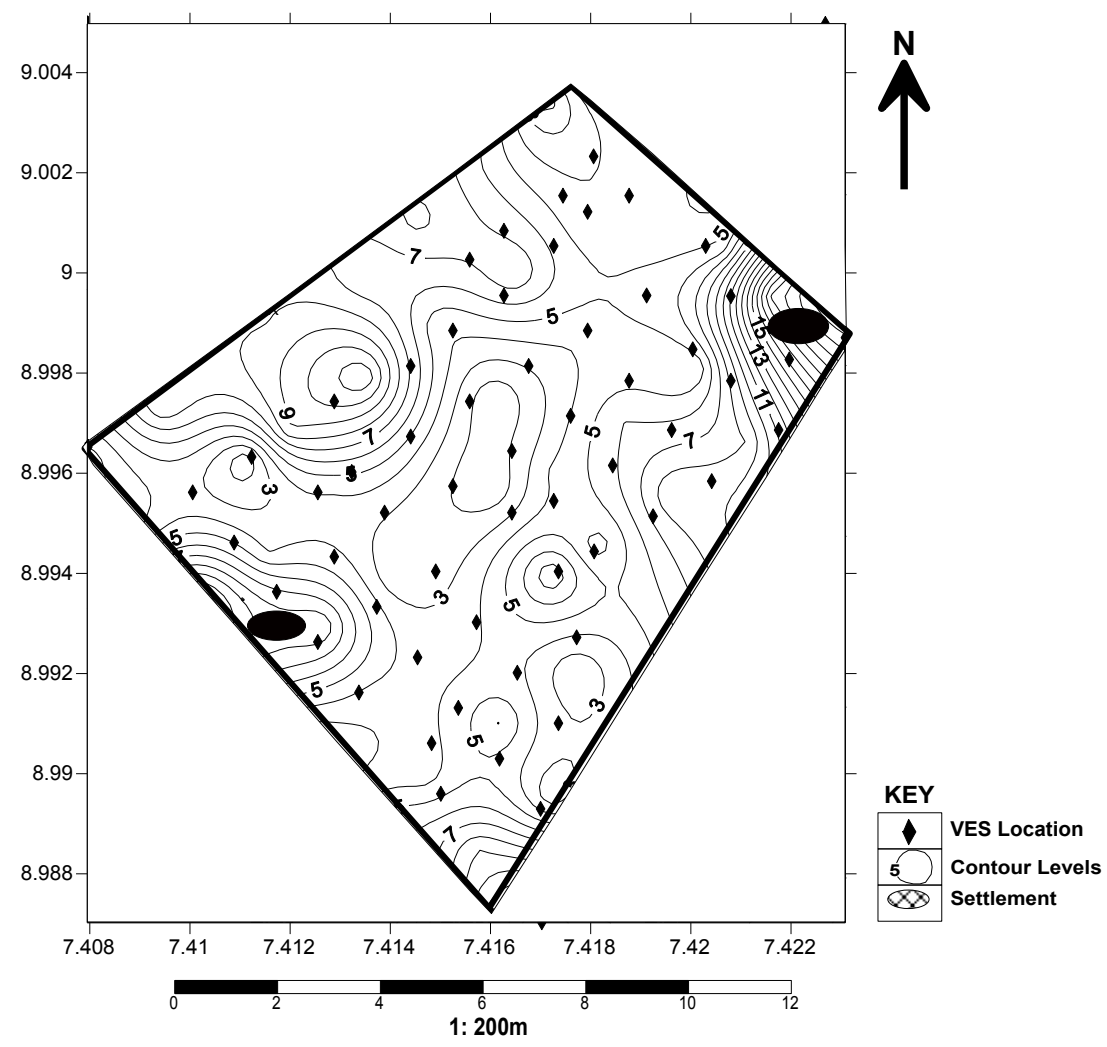

Fig. 9: Isopach Map of the Overburden

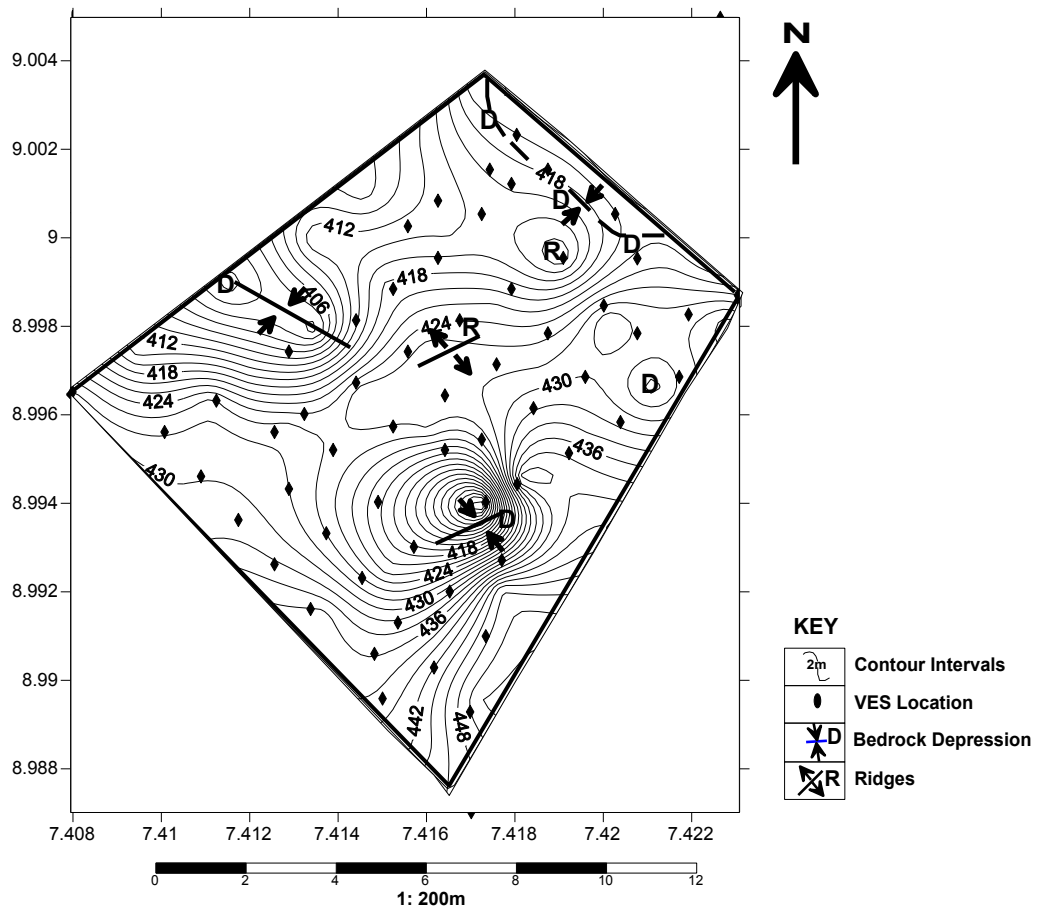

Fig. 10: Bedrock Relief Map

\section{Geological Structures}

Fig 11 shows the structural map of the area as derived from the bedrock relief map and geo-electric sections. The major structural trends strike NE-SW, although the long axis of the bedrock ridges trend in the NNW-SSE and NNE-SSW directions. The ridge marked R2 is separated from R3 by steep, deep subsurface depression 
which appear to influence the stream flowing from the SE to the NW (Fig.11). The quarries which have been abandoned due to complete submergence by groundwater from the fractures are evidences which point to the fact that the central area have been tectonically affected and should be the target zones/areas for groundwater development. However, for high rise buildings and civil engineering structures, the faulted areas should be avoided.

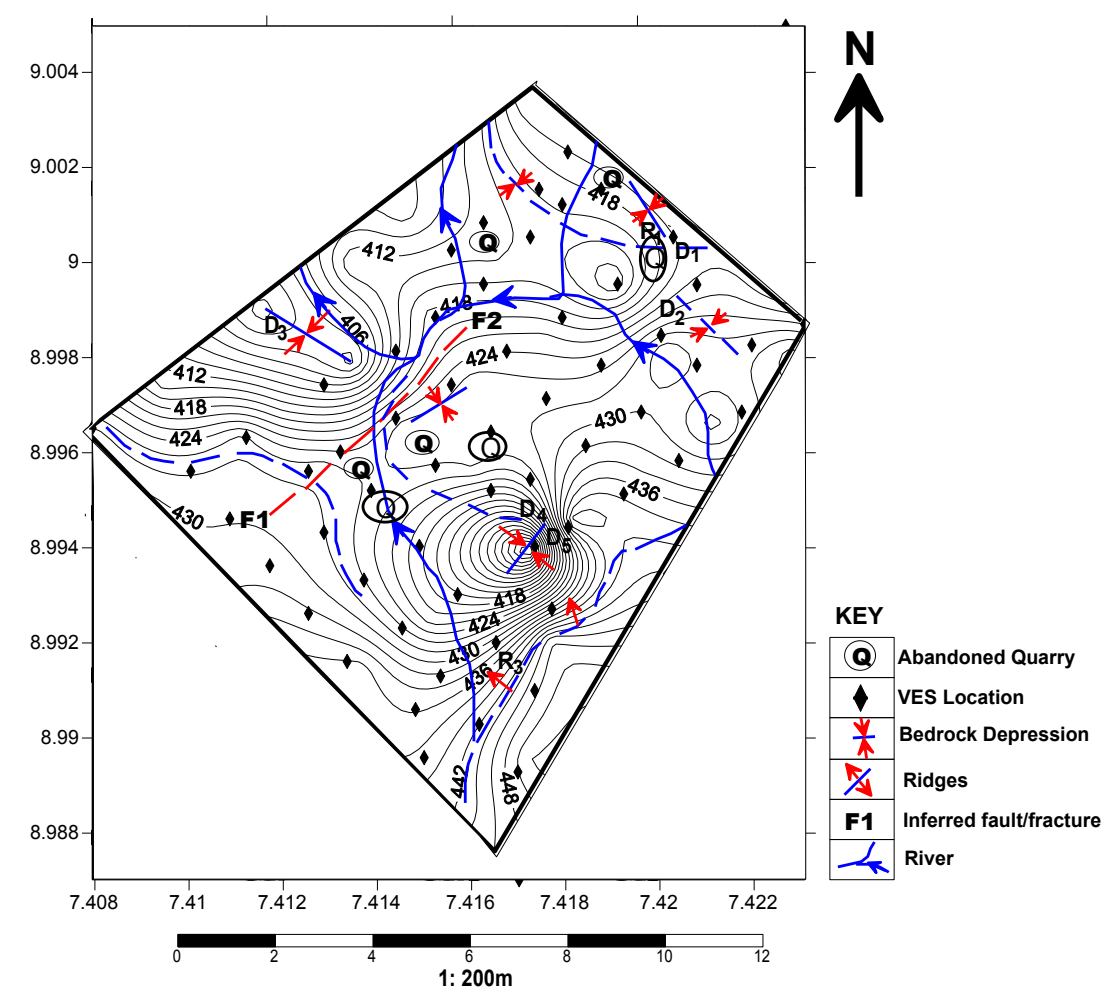

FIG.11: Structural Map of the Bedrock

\section{Hydro geologic Significance of Weathered Overburden and Bedrock Relief/Structures.}

In basement terrain, weathered overburden thickness, bedrock relief and structural setting are of significance in groundwater resources evaluation (Omosuyi et'al, 2003). Weathered overburden, if significantly thick and resistivity suggest saturated condition, is considered significant as water bearing layer.

Also, basement fractures/sheared bedrock may likely contain groundwater as a result of water accumulation in the fractures or joints. Based on the sections, maps and the VES interpretation, groundwater potential of the area is characterized (Fig. 12).

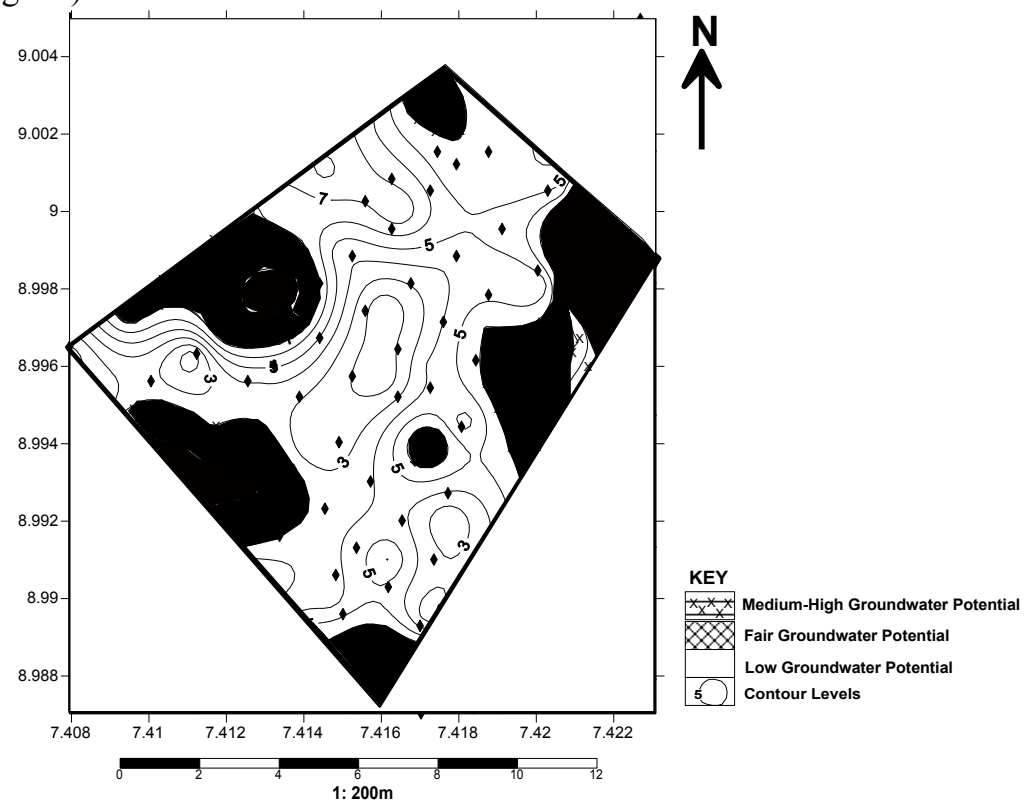

FIG.12 : Groundwater Potential Map 
The sections (Fig.4-6) and map (Fig.9) reveal relatively thick overburden (10-24m) in some isolated areas and may constitute target areas for groundwater development. The highly fractured or faulted area around the middle sections, near the abandoned quarries is potential area for groundwater resources development. However, for civil and building structures, the area could be problematic which can lead to structural failures.

\section{Conclusion And Recommendation}

The geo-electrical parameters obtained from the geo-electrical resistivity sounding (VES) data interpretation were used to establish the depth to basement, geological structures and groundwater potential of the study area. These parameters or factors are important in infrastructural development planning.

These findings are envisage to provide reliable background or baseline information for an elaborate geotechnical investigation for the area taking into consideration that all sectors of the FCT, Abuja have been earmarked for infrastructural development.

It is therefore, pertinent to note that the area investigated, most especially in the middle section, where it has been affected tectonically should be investigated further using integrated geophysical method and satellite imagery to give a clearer geological and geophysical disposition of the structures, which is very important for groundwater development and for decision in siting of building and civil engineering structures.

\section{Acknowledgement}

The authors wish to acknowledge the contributions of Mr. Muru I.N, Miss Linda Dakat, Nantap Ayuba, Yoila Yohanna and George Dogun who assisted with the field work. Mr. Joel Shikgolla Peter typed and digitized the maps and other figures.

\section{References}

[1]. ABU Consults Nigeria Ltd. (1999). Subsoil and Geophysical Investigations for Katampe District, FCT. FCDA.

[2]. Akintorinwa O.J. and Adeusi FA 2009. Integration of Geophysical and Geotechnical Investigation for a Proposed Lecture Room Complex at the Federal University of Technology, Akure, SW Nigeria. Ozean Journal of Applied Sciences (3) pp241 -254.

[3]. Federal Republic of Nigerian (1979) Master plan for Abuja-The federal Capital Territory of Nigeria.

[4]. Idornigie IA and Lawal MA 2006. Use of the electrical resistivity method in the Investigation of the axis of a small earth dam. African Journal of Natural Sciences Vol 9, pp 85-96.

[5]. Offodile, ME 2006. The Place of Geology in the Infrastructural Planning and Development of the Federal Capital Territory in Geological Science Series Vol 1, No.1.

[6]. Olorunfemi M.O. and Mesida L.A. (1987). Engineering Geophysics and its Application in Engineering Site Investigation: A case study from Ile-Ife Area. The Nigerian Engineering Vol.22.No.2.

[7]. Olorunfemi M.O and Okhue (1992). Hydrogeologic and geologic significance of geo-elelctric survey at Ile-Ife. Nigerian Journal of Mining Geology Vol. 28 No.2 pp221-229.

[8]. Omosuyi G.O Arikanselu P.A (2003). Geophysical Investigation for Groundwater around Obanla-Obakekere in Akure area within the Basement Complex of Southwestern Nigeria. Journal of Mining and Geology Vol.39 (2) pp 109-116

[9]. Vander Velpen BPA $(1988,2004)$. Win Resist Version 1.0 Msc Research Project, ITC, Delf Netherland 